\title{
THE KNOWLEDGE REGARDING BIO-MEDICAL WASTE AND ITS MANAGEMENT AMONG CLASS IV WORKERS
}

Mr. Vishnu Kumar Swarnkar* I Dr. Rajendra Prasad Sharma**

*Ph.D Scholar \& Assistant Professor, Upchar College of Nursing, Jaipur, Rajasthan, India.

${ }^{* *}$ Associate Professor, Mahatma Gandhi Nursing College, Jaipur, Rajasthan, India. DOI: http://doi.org/10.47211/idcij.2021.v08i03.002

\begin{abstract}
The biomedical waste [management \& handling] rules, 1998 gives a wider definition of biomedical waste, covers different sources generation of biomedical: includes different types of biomedical waste. Biomedical waste management \&amp; handling rules 1998 of India provide different waste categories like human anatomical waste, animal waste, microbiological \& biotechnology waste, waste sharps, discarded medicine etc. The quantity of biomedical waste generated per bed per day will vary depending upon the type of health problems, the type of care provided \&amp; the hospital waste management practices. It is estimated that the hospital in India generates around 1-2 kg/bed/day of biomedical waste in a general practitioner's clinic. Approximately $75 \%$ of biomedical waste is as harmless as other municipal waste, the remaining $25 \%$ however differ from others.
\end{abstract}

Key Words: Biomedical Waste, Segregation, Sanitation, Hazardious.

\section{ABOUT AUTHORS:}

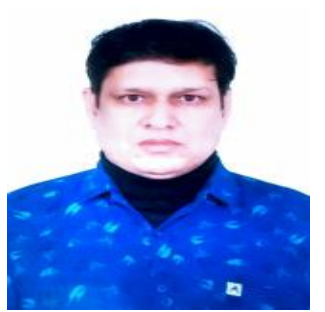

Author Mr. Vishnu Kumar Swarnkar is working as Assistant Professor at Upchar College of Nursing, Jaipur, Rajasthan, India. He has a MSc (N) B.Sc (Bio.) M.A. (His) LLB

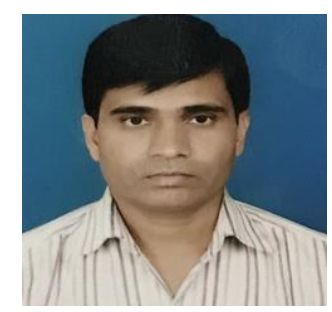

Author Dr. Rajendra Prasad Sharma is working as Associate Professor at Mahatma Gandhi Nursing College Jaipur, Rajasthan, India. He has a Research Guide for PG and Ph.D. Scholar. He has Presented Papers at Various Seminars and Conferences 


\section{INTRODUCTION}

Biomedical waste management defines waste management as the practices \&amp; procedures or the administration of activities that provide for the collection, source separation, storage, transportation, transfer, processing, treatment \&amp; disposal of waste .Biomedical waste management is a routine procedure of hospital administration as prescribed by law .Hospital waste, hospital acquired infection, transfusion transmitted diseases, rising incidence of hepatitis B, HIV \&amp; Other diseases, create potential threat of infection, contamination \&amp; serious health hazards to doctors, nurses, ward boys, support staff, sanitation workers, rag pickers \&amp; other health care workers. Who are regularly exposed to biomedical waste as an occupation hazards as well as general public in the surrounding area. Biomedical waste should be collected at the site of generation only. Segregation aims to keep the harmful \&amp; infected material separate from the harmless \& noncontagious waste for this purpose, use of specially color dustbin \&amp; plastic bag is mandatory. Even though only $15 \%$ to $20 \%$ of hospital wastes that is biomedical waste generated from biological sources or is used in the diagnosis, prevention or treatment of diseases is infectious \&amp; hazardous but if it is not segregated at the source of generation \&amp; is mixed with other nonhazardous waste then $100 \%$ waste Become hazardous. Some time, even the sharps used in the health care create risk of injuries leading to infection to all categories of hospital personnel, patient \&amp; waste handler \& public living in the vicinity of hospital.

Biomedical waste management is a multidimensional \&amp; multidisciplinary area touching every field of medicine, scientific research, management techniques, law, \& environment as well as social \&amp; political issues.

\section{NEED OF THE STUDY}

The establishment of large hospitals where hundreds to thousands of patients are treated, it has created a serious problem of biomedical waste management. The seriousness of improper biomedical waste management was brought to the light during summer 1998. In India studies have been carried out at local/regional levels in various hospitals, indicate that roughly about $1-5 \mathrm{~kg} / \mathrm{bed} / \mathrm{day}$ to waste is generated. Among all health care personnel, ward boys, sweepers, operation theatre \& laboratory attendants have come into contact with biomedical waste during the process of segregation, collection, transport, storage \&amp; final disposal. The knowledge of medical, paramedical staff \&amp; ward boys, sweepers about the biomedical waste management is important to improve the biomedical waste management practices. The biomedical waste requiring special attention includes those that are potentially infectious, sharps, example needle , scalpels, objects capable of puncturing the skin, also plastic ,pharmaceutical \&amp; chemically hazardous substances used in laboratories etc.

A need clearly exists for education of at risk health care workers on the nature of the risk exposed by the medical waste \&amp; methods for their proper handling. Biomedical waste treatment facilitates are mostly licensed by the local government that have specified rules \&amp; laws regarding the possessing \&amp; disposal of waste. The laws ensure that general public is protected from of contamination. Worldwide, approximately 2 million workers experience a needle stick injuries each year. A needle stick injury could transmit hepatitis B, hepatitis- C or the Human Immunodeficiency Virus HIV. The risk of infection after exposure to the infected. Now a day handling; disposal of biomedical waste has emerged as a major problem in India. If the 4th class workers have inadequate knowledge regarding handling \&amp; disposal of health care waste may lead to transmission of infectious disease. The groups most at risk are nurses, paramedical staff, waste management operators, scavengers. The management of hospital waste requires diligence care from a chain of people through collection workers \&amp; finishing with disposal operators. If any of these lack knowledge or careless in their work, the chain would be broken \&amp; dangers to infection would follow.

\section{OBJECTIVE OF THE STUDY}

1. To assess the existing level of knowledge regarding bio-medical waste its management among the class IV workers (group D)

2. To find out the association of the knowledge regarding biomedical waste; its management among class IV workers (group D) with selected demographic variables.

\section{HYPOTHESIS}

H1: There will be significant association between the knowledge regarding biomedical waste \&amp; its management among class IV workers (group D) with their selected demographical variables.

\section{ASSUMPTION}

Class IV workers will have some knowledge regarding biomedical waste \&amp; its management.

\section{RESEARCH METHODOLOGY}

Research methodology is a way of systematically solving the research problems. It explains the steps that are generally adopted by a researcher in studying the research problem along with the logic behind them. 


\section{RESEARCH DESIGN:}

The research design spells out the basic strategies that the researcher adopts to develop information that is accurate and interpretable and incorporates some of the most important methodological decisions that the researcher makes in conducting a research study.

The research design is the overall plan for obtaining answers to the questions being studied and for handling some of the difficulties encountered during the research process.

\section{POPULATION:}

Population is defined as an entire group or objects or events which will have at least one characteristic in common and must be defined specifically and unambiguously. ${ }^{[65]}$

The population for the present study comprised of the class IV workers attending selected hospitals at Jaipur Rajasthan.

SAMPLE: Sample refers to subset of the population that is selected to participate in a particular study.

In this study, the sample consists of class IV workers who fulfilled the inclusion criteria.

SAMPLE SIZE:

A sample size is a small portion of a population selected for the study. It constitutes a subset of total population. The sample of the present study comprised of 100 class IV workers who met the inclusion criteria were selected for the study.

\section{SAMPLING TECHNIQUE}

Sampling is the process in which representative units of a population are selected for study in a research investigation.

Non-probability sampling is where samples are selected based on the judgment of the researcher to achieve particular objectives of the research at hand.

Purposive sampling technique is a strategy in which the researcher's knowledge of the population and its elements used to select sample which are typical to the population.

Purposive sampling technique, a type of non-probability sampling approach was used to select the sample of 100 class IV workers.

Data analysis and interpretation

Table-1: shows the frequency and percentage distribution of demographic variables among the class IV workers.

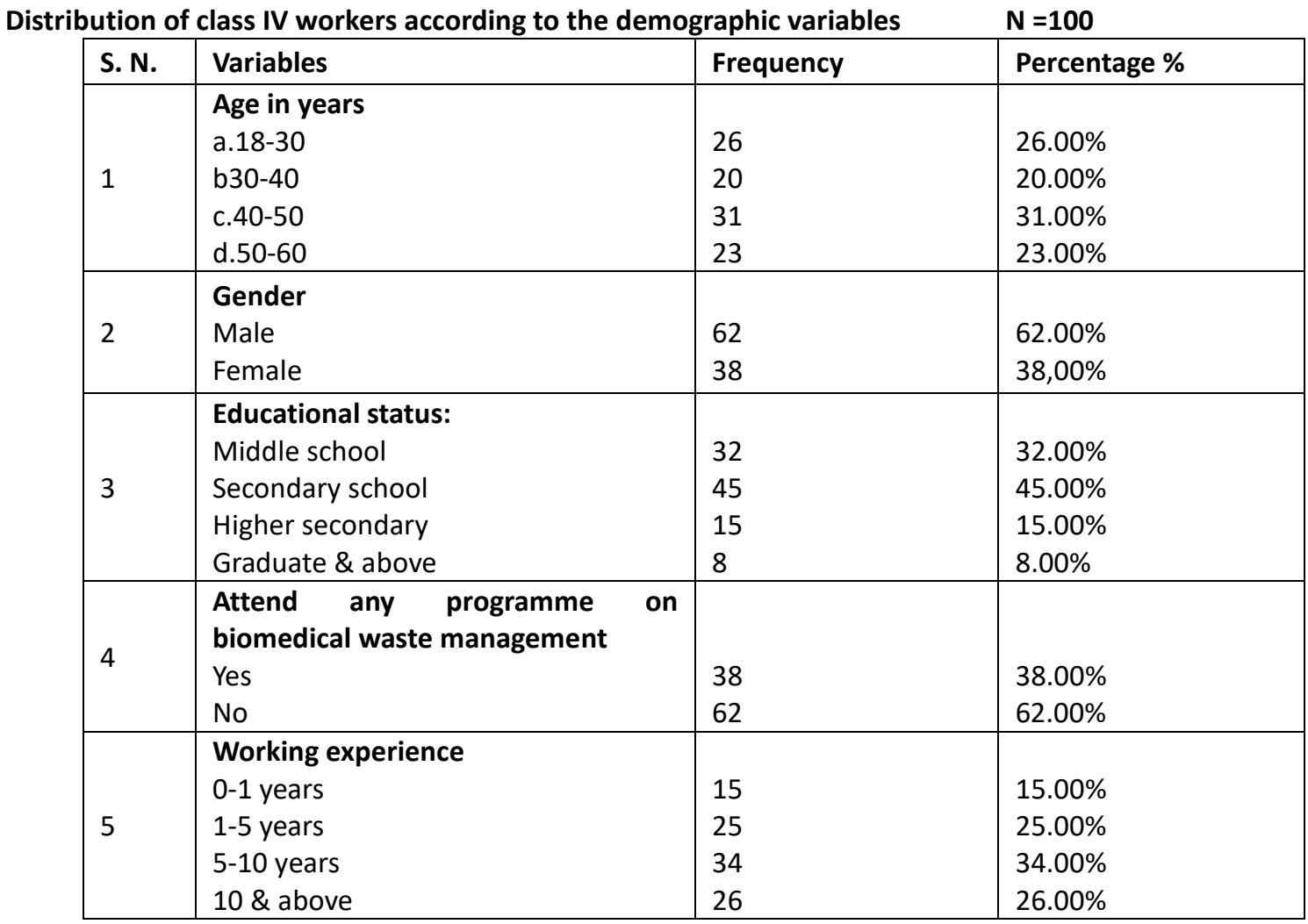


Table-2: Assessment of knowledge of the class IV workers regarding biomedical waste \& management.

\begin{tabular}{|l|l|l|l|l|}
\hline S. N. & Level of knowledge & \% score & No. of class IV $\%$ of class IV & workers \\
& & & workers \\
\hline 1. & Poor & $0-40 \%$ & 42 & 42 \\
\hline 2. & Average & $41-50 \%$ & 32 & 32 \\
\hline 3. & Good & $51-75 \%$ & 20 & 20 \\
\hline
\end{tabular}

Distribution of class IV workers according to their level of knowledge regarding biomedical waste \& its management.

Assessment of the level of knowledge of class IV workers showed that $42 \%$ of the class IV workers had poor knowledge regarding biomedical waste \& its management, $32 \%$ had average knowledge and $20 \%$ of the class IV workers had good knowledge regarding biomedical waste \& its management \& $6 \%$ of the class IV workers had very good knowledge regarding biomedical waste $\&$ its management.

Table-3: Association between knowledge regarding class IV workers and selected demographic variables Description of overall \& area wise score, Mean, Median, SD, Mean percentage of knowledge scores of class IV workers regarding biomedical waste $\&$ its management.

\begin{tabular}{|l|l|l|l|l|l|l|}
\hline S.N. & Area & Max & Mean & Median & Mean\% & S.D. \\
\hline 1 & $\begin{array}{l}\text { Siomedical waste \& } \\
\text { biomedical waste hazards }\end{array}$ & 4 & 1.55 & 2 & $38.78 \%$ & $0.58 \%$ \\
\hline 2 & $\begin{array}{l}\text { Biomedical waste } \\
\text { management (segregation } \\
\text { \& safety }\end{array}$ & 16 & 8.38 & 8 & $52.37 \%$ & $1.94 \%$ \\
\hline $\mathbf{3}$ & $\begin{array}{l}\text { Biomedical waste } \\
\text { management storage, }\end{array}$ & $\mathbf{1 0}$ & $\mathbf{3 . 4 5}$ & $\mathbf{3}$ & $\mathbf{3 4 . 5 1 \%}$ & $\mathbf{1 . 4 8 \%}$ \\
\hline Overall & & $\mathbf{3 0}$ & $\mathbf{1 3 . 4 3}$ & $\mathbf{1 3}$ & $\mathbf{4 4 . 7 6 \%}$ & $\mathbf{3 . 1 9 \%}$ \\
\hline
\end{tabular}


Table-4: knowledge score with the selected socio-demographic variable of class

\begin{tabular}{|c|c|c|c|c|c|}
\hline \multirow{2}{*}{ No } & \multirow{2}{*}{ Variable } & \multicolumn{2}{|l|}{ Chi square } & \multirow{2}{*}{ d.f } & \multirow{2}{*}{ Level of Significance } \\
\hline & & Calculated value & Tabulated value & & \\
\hline 1 & $\begin{array}{l}\text { AGE } \\
18-30 \\
30-40 \\
40-50 \\
50-60\end{array}$ & 19.34 & 16.92 & 9 & $\begin{array}{l}0.05 \\
\text { NS }\end{array}$ \\
\hline 2 & $\begin{array}{l}\text { Gender } \\
\text { Male } \\
\text { Female }\end{array}$ & 11.56 & 7.81 & 3 & $\begin{array}{l}0.05 \\
\text { NS }\end{array}$ \\
\hline 3 & $\begin{array}{l}\text { EDUCATIONAL STATUS } \\
\text { Middle School } \\
\text { Secondary } \\
\text { Higher secondary } \\
\text { Graduate \& above }\end{array}$ & 13.96 & $\begin{array}{l}16.92 \\
16.92\end{array}$ & 9 & $\begin{array}{l}0.05 \\
\text { NS }\end{array}$ \\
\hline 4 & $\begin{array}{l}\text { Attend any programme } \\
\text { Yes } \\
\text { No }\end{array}$ & 2.44 & 7.81 & 3 & $\begin{array}{l}0.05 \\
\text { NS }\end{array}$ \\
\hline 5 & $\begin{array}{l}\text { Working experience } \\
0-1 \text { years } \\
1-5 \text { years } \\
5-10 \text { years } \\
10 \text { years \& above }\end{array}$ & 6.3 & 16.92 & 9 & 0.05 \\
\hline
\end{tabular}

The obtained values are less than the table values at the 0.05 level of significance, the null hypothesis accepted and there is no significant association between the age, gender ,knowledge scores of participants.

The obtained values are greater than the table values at the 0.05 level of significance, the null hypothesis rejected and there is significant association between the age, and gender and knowledge scores of participants.

\section{CONCLUSION}

The main reason for high spread of infection, diseases in India is that many health care workers are not aware of the measures that are available to prevent diseases in biomedical waste management as well as basic information in self care during waste management. Many do not receive timely help because of either they are unaware of the help available or help is not with in the reasonable distance

Biomedical wastes are one of the major causes of infection in the hospital settings. So it's the responsibility of the hospital authority along with the health team to collect, segregation, transport \& store \& disposal it off to safeguard the people from hospital acquired infection.

Today, nurses and other health care workers have an important role in health promotion, bring the health care 
manufacturers. The management nurse is posed to a unique function of identifying and providing huge standard of biomedical waste management that contributes to the maintenance of good health and minimize the severity of the disease.

\section{REFERENCES}

1.Dr. Sujata pawar, a review of biomedical waste (management \& handling) rules, 1998.Online law journal,ISSN 2319-8338, 2015.

2.P.Basheer Shebeer $\&$ Khan S. yassen, a concise text book of advance nursing practice, first adition 2012, emmess medical publishers, page No.335. http:/www. medlndia. Net/news/over-haff of biomedical waste disposed with municipal garbage - 67655-1.ht $\mathrm{m}$ last accessed on May 15, 2015.

3. Vetrivel chezian sengodan, manivannon shivapriya, biomedical waste minimization in the orthopaedic ward in tertiary care hospital in Tamil nadu, volume-5, 2013, page number 93-98.

4. Tukaram B. Zagade, Dr. Asha K. Pratinidhi, assessment of effectiveness of educational intervention on knowledge among biomedical waste handlers, international journal of science \& research, volume 3,issue 9, 2014, page No. 1-3.

5. www.pubmed index for Medline

6. www.elseivier health.com 